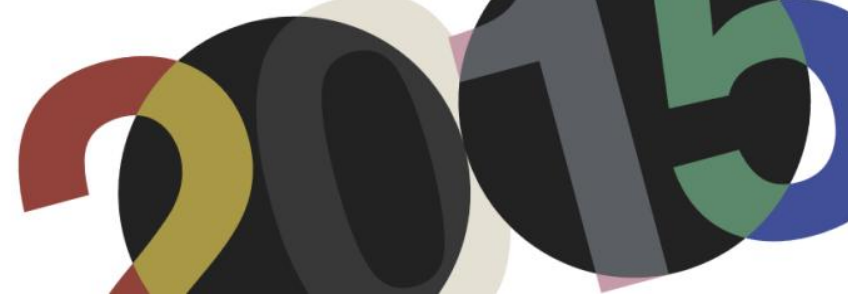

DOI: http://dx.doi.org/10.4995/LC2015.2015.647

\title{
On Diagonal Time in Le Corbusier's Visual Arts Center
}

\author{
M. Jasper \\ University of Canberra
}

\begin{abstract}
This paper introduces the concept of diagonal time as an interpretive category for understanding composition strategies and spatial effects in certain projects of Le Corbusier. It is organized around two propositions: first, there is a largely untheorised temporality created in certain works of modernist architecture and those of Le Corbusier in particular; second, this temporality can be characterized as one not bound to a vision in motion nor does it require a body's movement to gain presence. In order to test these propositions the paper undertakes a formal analysis of Le Corbusier's Visual Arts Center, Cambridge, Massachusetts (1960-1964). The Visual Arts Center's apparent reliance on movement for its coming into being is interrogated by focusing on other devices and strategies. Four such strategies are explored: oblique and transverse form relationships, expressive volumes, figure/ground ambiguities, and voided centres. Building on the archival and criticalhistorical work of Curtis and Sekler, the paper advances a line of inquiry into modernist architecture's trajectory only alluded to in secondary scholarship, contributes to understanding key formal elements in an important building from Le Corbusier's late period, and addresses a major conference theme, that of the transversal.
\end{abstract}

Keywords: architecture; composition; Le Corbusier; space; temporality; Visual Arts Center.

\section{Introduction}

“time ... increasingly appears for itself," Gilles Deleuze ${ }^{1}$

\subsection{Propositions}

In his 1965 essay on Le Corbusier's just opened Visual Arts Center, published as an homage following Le Corbusier's death in August of the same year, John Hejduk (1929-2000) conjectures that the building generates a cut in time. Different from a temporality conceived as linear and progressive, and as implied in the title of the essay, for Hejduk the building creates architectural conditions that are "out of time". This insistence on the building's capacity to engender a time out of joint, one liberated from movement and structure according to Hejduk, implies a specific kind of architectural temporality. It also highlights a too little explored aspect of modernist architecture more commonly discussed in terms of formal and spatial characteristics.

Taking Hejduk at his word, a number of general questions are raised. How are buildings and projects composed such that time is confronted? Is there a specifically modernist concept of time, a modernist mode for the creation and expression of time? Just as there are different space concepts, are there different architectural concepts of time and if so how do they work and what are their distinguishing characteristics?

\footnotetext{
1 Deleuze, Gilles: Cinema 2 The Time-Image. Translated from the French by Hugh Tomlinson and Robert Galeta Minneapolis: University of Minnesota Press, 1989. p. xi.

${ }^{2}$ Hejduk's essay is first published as "Hors du temps dans l'espace" in L'Architecture d'aujourd'hui, $\mathrm{N}^{\mathrm{o}} 122$, SeptemberNovember 1965. pp. xi, xxiii. An expanded version referenced in this paper is contained in John Hejduk, Mask of Medusa: Works 1947-1983. Edited by K Shkapich. New York: Rizzoli International, 1985.
} 
Another way to formulate the question: is Hejduk finding evidence of a liberation of time from movement? Is it a liberation similar to that which Gilles Deleuze (1925-1995) discerns in certain post-1945 works of art and cinema such that a pure time is made palpable and architectural-plastic qualities released independent of movement?

Two propositions - simultaneously thematic, methodological and conceptual - provide a preliminary framework for responding to these questions. The first proposition is that there is a largely untheorised temporality created in certain modernist works of architecture and those of Le Corbusier in particular. The second proposition: this temporality can be characterized as one not bound to a vision in motion nor does it require a body's movement to gain presence. In certain modernist works of architecture, rather, there is a condition of vibration and energy already contained or produced by the building independent of movement. Time, to take Deleuze's implied formula, has "gone creative", 3 and this condition perhaps resembles or renders physical a concept of direct time in the realm of architecture.

To begin to investigate these propositions I examine a building that engages overtly movement and thus by implication imbeds or releases a concept of time. The Visual Arts Center, Cambridge, Massachusetts (19601964, hereafter VAC) also known as the Carpenter Center for the Visual Arts, is an important project in Le Corbusier's late period and provides material for the analysis ${ }^{4}$. VAC's apparent reliance on circulation for its coming into being is tested by focusing on other devices, strategies, and formal effects. Both on the surface and perhaps in reality it treats the spiral, the diagonal, and the torqued perceptions produced as generators of singular effects, ones perhaps bound to, rendering, or recording a concept of time.

In the Visual Arts Center I suggest we are confronted with forms of simultaneity and conditions of time as overlapping durations. The temporality rendered in VAC, that is, is an always already compressed time, one different from that which is composed by a line of images or vignettes and thus is reliant neither on futures nor pasts. This state is the consequence in part of compressions and releases which work to create folds in, or give thickness to, a kind of temporality potential in modernist architecture and which is labelled for the purposes of this paper diagonal time. This condition is named diagonal time to differentiate it from a linear past-present-future time and a purely empirical succession of things.

\subsection{Approach}

To begin to frame an approach to the concept of a temporality specific to certain works of modernist architecture, I borrow the notion of direct time as theorised by Deleuze and deployed most fully in his Cinema 2. The Time Image. In Cinema 2, Deleuze proposes that in some mid-twentieth-century films and works of fine art a new relationship of movement and time is made visible. Time is no longer subordinate to movement, he writes, and a reversal occurs such that "time ceases to be the measurement of normal movement, it increasingly appears for itself ${ }^{\prime 5}$.

\footnotetext{
${ }^{3}$ Deleuze does not specifically propose this effect, but it's appropriateness is suggested when he writes in relation to the cinema image: "What is specific to the [time-] image, as soon as it is creative, is to make perceptible, to make visible, relationships of time which cannot be seen in the represented object and do not allow themselves to be reduced to the present.." Deleuze, 1989, p.xii.

${ }^{4}$ Standard references include W. E. Boesiger (Ed.): Le Corbusier et son atelier rue de Sèvres 35. Oeuvre complète, volume 7 , 1957-1965. Zurich: Les Editions d'Architecture, 1965, pp. 54-67. Sekler, Eduard F. and Curtis, William: Le Corbusier at Work. The Genesis of the Carpenter Center for the Visual Arts, Cambridge, Harvard University Press, 1978.

${ }^{5}$ Deleuze, 1989, p.xi.
} 
Requiring further elaboration in subsequent studies, I believe a phenomenon similar to that which Deleuze discerns in the realm of philosophy, cinema and certain works of painting and sculpture can be claimed for architecture. An examination of projects that release or make concrete a deleuzian direct time, one not bound to a promenade architecturale from the point of view of time may, in turn, reveal a range of formal moves and composition devices at work along with their resultant formal-spatial effects. A preliminary analysis of VAC will be used to explore this idea.

The Visual Arts Center freeze stops a moment in time and thus illustrates an architectural concept of direct time by means of a number of devices and strategies. (Fig 1) Four such aspects are briefly explored: oblique and transverse form relationships; ambiguity in figure/ground relationships; expressive volumes; and voided centres that create intensity independent of animating factors.

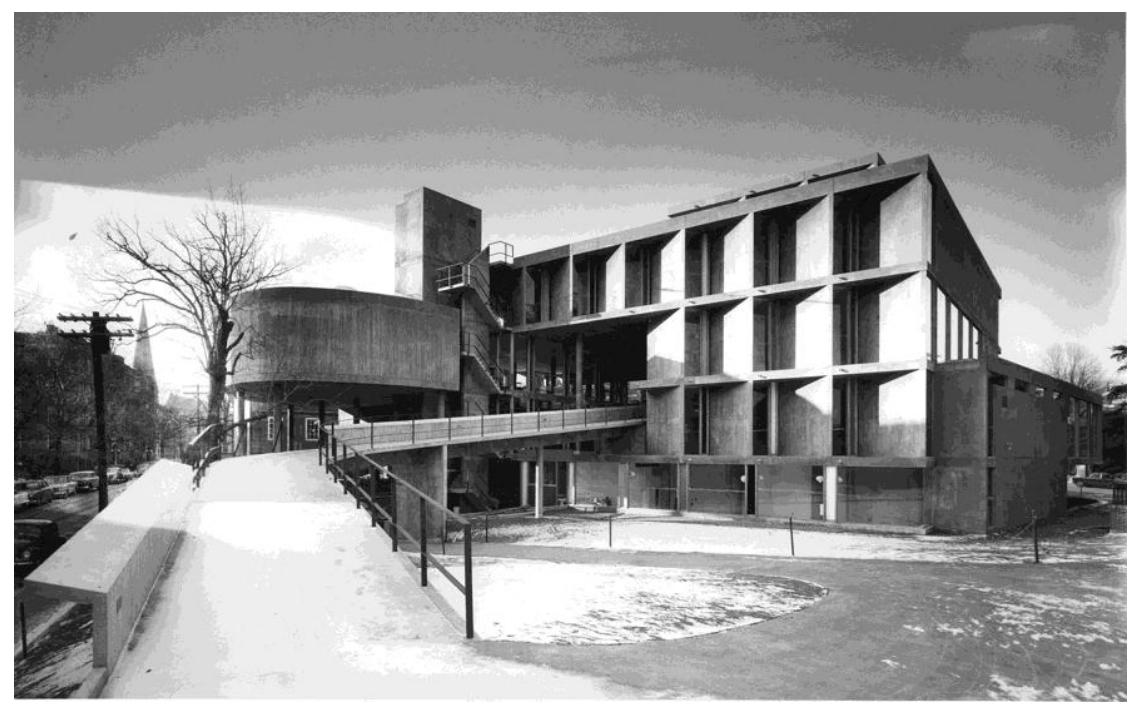

1. Le Corbusier, Visual Arts Centre, view from Prescott Street. (C) Fondation Le Corbusier-ADAGP, 2015.

\subsection{Scholarly context and structure}

In the Oeuvre complète presentation of the project, Le Corbusier highlights the autobiographical role of the

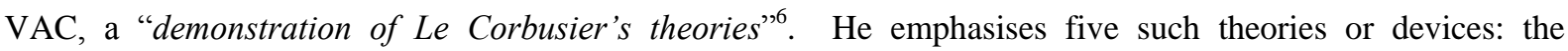
interpenetration of internal and external space, the use of rough concrete (béton brut), the ramp as organising device, the free plan, and the use of brise-soleil. Different from Le Corbusier's focus on these formal and spatial devices, I believe VAC can be read to display a turn in his thinking and a specific notion of time, one whose potential for practice and theory has yet to be examined or exploited.

Taking primarily visual material as the object of study, I start with observations on approximate configurations aligned with four aspects and then move to identify their specificity in order to test how certain motives and effects might be generalized into architectural strategies that work directly on time. In so doing I hope to begin to identify the formal logics and morphologies underlying the building and their potential extension as an interpretive and creative category. In this way I endeavour to follow what Colin Rowe (1920-1999) characterized as a Wölflinian style of "intensive critical workout".

\footnotetext{
${ }^{6}$ Le Corbusier, Oeuvre complete 1957-1965, p.54.

${ }^{7}$ Colin Rowe: The Mathematics of the Ideal Villa and Other Essays, Cambridge, The MIT Press, 1976. p.16.
} 
I work from published drawings, photographs both recent and dating from the time of the building's completion, writings of Le Corbusier, and secondary writings. I have benefited, as do all scholars working on this building, from the archival and critical-historical efforts of William Curtis as well as that of Colquhoun, Sekler, Serenyi, and von Moos in particular. These scholars provide important interpretations of the building's design history, speculate on Le Corbusier's intentions, and interpret the role of the building in Le Corbusier's life-work.

Von Moos discusses aspects of the project to highlight Le Corbusier's typological design method and the metaphoric nature of certain forms ${ }^{8}$. Sekler's analysis focuses on the provenance of forms and spatial ideals and the relation of Le Corbusier's painting to this architectural practice. Curtis highlights in his important survey, recently published in an expanded second edition, formal inventions, transformations of established elements and the condensation of spatial ideas but he does not specifically discuss temporality ${ }^{9}$. In terms of method, and though he does not directly discuss VAC, Alan Colquhoun provides an exemplary and elegantly spare approach to Le Corbusier's late period work and I have benefited from his comparative approach ${ }^{10}$. Similarly, Peter Eisenman's Ten Canonical Buildings provides a methodological framework for the present essay, one whose depth and breath of interrogation a longer study of VAC will attempt to approach ${ }^{11}$.

Far from attempting to establish the origins of forms or ideas - either within the work individually or within the context of a trajectory of Le Corbusier's work - I focus on the relatively modest aim of conjecturing on how the project works on time, attempting a preliminary description of the devices and formal moves used and the consequent architectural effects from the point of view of time.

Drawings published in Le Corbusier at Work of the building in design development phase and as built constitute primary analytic materials. They compliment the drawings published in the Oeuvre complète 1957-1965 which record an interim phase in the design process. The latter for example show an internal horseshoe ramp connecting Levels 2 and 3 that was abandoned. Secondary writings from the period and more recent scholarship on Le Corbusier provide historical and critical context. Floor plans are named according to the convention of the Oeuvre complète, thus the ground floor is Ground Level, the next floor up is Level 1, and so on.

Throughout I use the name of the building as it is given in the Oeuvre complète and as referenced by Le Corbusier in project correspondence published in Le Corbusier at Work, that is, Visual Arts Center, abbreviated as VAC. Drawings from Le Corbusier's office carry the office's characteristic three-character project name shorthand, in this case VAC-BOS for Visual Arts Center, Boston, and thus the shorthand naming convention used here is consistent with the practice of the 35 rue de Sèvres office.

The paper is organized in three sections, the first setting out the generating propositions, materials of study, and the approach. Section two proffers a formal analysis of Le Corbusier's Visual Arts Center according to four themes: diagonals, expressive volume, ambiguities, and voided centre. Section three returns to the proposition of an architectural concept of time, responds to the opening questions, and outlines future areas of research as a form of conclusion.

\footnotetext{
${ }^{8}$ von Moos, Stanislaus: Le Corbusier. Elements of a Synthesis. Cambridge, Mass.: The MIT Press, 1979. pp. 85, 87.

${ }^{9}$ Curtis, William J. R.: Le Corbusier. Ideas and Forms, 2nd ed. London: Phaidon Publishing, Inc., 2015.

${ }^{10}$ Colquhoun, Alan: "Formal and Functional Interactions: A Study of Two Late Buildings by Le Corbusier". In Essays in Architectural Criticism: Modern Architecture and Historical Change. Cambridge, Mass.: The MIT Press, 1981. pp. 31-41.

${ }^{11}$ Eisenman, Peter: Ten Canonical Buildings 1950-2000. New York: Rizzoli, 2008.
} 


\section{Analysis}

"ACTION OF THE WORK (architecture, statue or picture) on its surroundings... REACTION OF THE SETTING: ... the whole environment brings its weight to bear on the place where there is a work of art, the sign of man's will, and imposes on it its deep spaces or projections, its hard or soft densities, it violences or its softnesses... In a complete and successful work there are hidden masses of implications, a veritable world which reveals itself to those whom it may concern, which means: to those who deserve it. Then a boundless depth opens up, effaces the walls, drives away contingent presences, accomplishes the miracle of ineffable space." Le Corbusier ${ }^{12}$

An examination of the project reveals at least four formal devices or composition strategies in play. These are diagonal and transverse planning, volumes treated as expressive space, ambiguities in figure-ground relationships, and an absent or voided centre. Each in some manner is rendered in VAC and goes beyond or differs from other formal-spatial conditions and motifs in Le Corbusier's work. Diagonal and transverse planning moves away from Le Corbusier's emphatic bias to frontality and cross-axial planning. Expressive volumes realised in lung-like figures disrupt a purely Domino reading. Ambiguities abound in the project and there is a blurring of figure-ground relations in favour of a mannered manipulation of contour and surface resulting in figure-figure readings. The centre, finally, is absent and calls for perhaps most emphatically to explain its potential an interpretation of the project's impact as engendering a specific kind of temporality.

\subsection{Diagonals, or going beyond frontality}

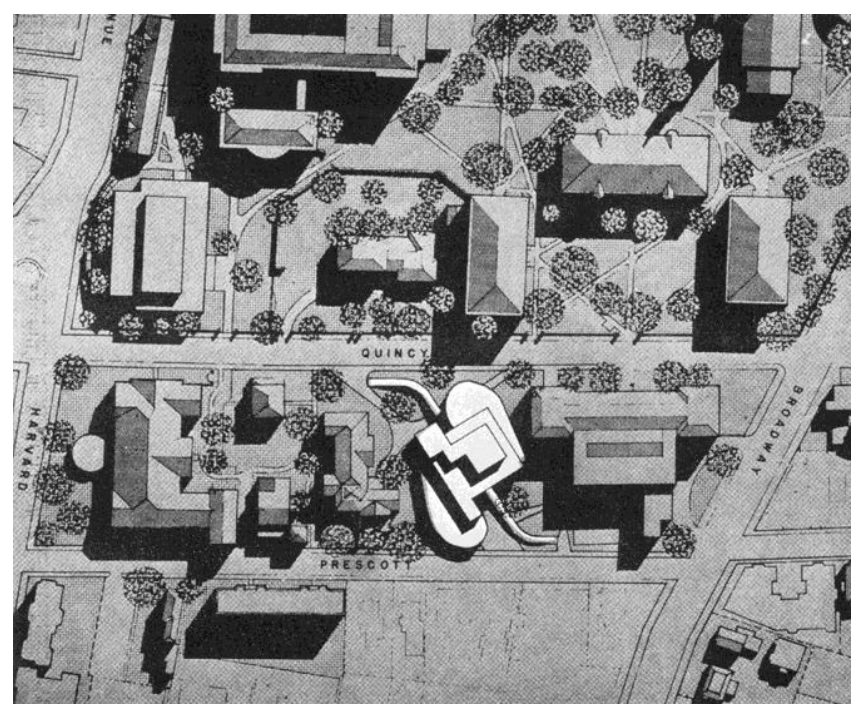

2. Le Corbusier, Visual Arts Center, Site Plan, with Prescott Street at the bottom and Quincy Street at the top of the frame, north is to the right of frame. (W. E. Boesiger (Ed.), Le Corbusier et son atelier rue de Sèvres 35. Oeuvre complète, volume 7, 1957-1965. Zurich: Les Editions d'Architecture, 1965. p.55 @ Fondation Le Corbusier-ADAGP, 2015).

The first thing that is striking when examining drawings or photographs of the project is the rotation of the building relative to the bounding orthogonal field of streets and buildings. (Fig. 2) There are at least two major

\footnotetext{
${ }^{12}$ Le Corbusier: New World of Space. New York and Boston: Reynal \& Hitchcock and The Institute of Contemporary Art, 1948. p. 8.
} 
consequences resulting from this rotation: peripheric tensions of the edge are created, and field extensions beyond the building volume engender an expanding space.

Rotation also creates conditions which challenge potential bay readings and disrupt frontal and cross-axial factors as everything in one sense is or has become diagonally engaged in a perimeter condition. In VAC oblique and transverse moves are at work throughout. Diagonal motions off the parallel streets of Prescott and Quincy initiate this condition. The Level 1 and 2 studios continue this non frontal logic with a spiralling and echeloned cascade along the outer edge of the lung-shaped spaces. The plans as published in the Oeuvre complète show a $\mathrm{U}$-shaped ramp connecting Levels 2 and 3 in a clock-wise spiral moving up the building, which if built would have continued and intensified the external ramp's momentum upward, or alternately have contributed to a corkscrew motion downward from the roof-top apartment and garden.

Frontal views are difficult to achieve and are deemed static; three-quarter views are favoured. Peripheral composition is sought over centralized, and interpenetration favoured over separation. Thus VAC can be seen to be centrifugally ordered though not purely: it is in part channelled and vertically stacked at the same time that it is self-bifurcating and horizontally distributed. This bifurcation might be characterised as creating a diptych condition, as an examination of sketches and the Quincy Street elevation reveal. (Fig. 3, 4, 12)

Out of these relations, a general, fairly constant diagonal condition is shown to exist. A review of the plans reveals a disposition different from the enfilade (room to room) plan and the poché (served and servant) plan. It is a case in certain floors of an open plan (Levels 1 and 2 for example) and in others a free plan (Level 3). The building favours transverse over cross-axial or longitudinal arrangements though as with other readings there is an ambiguity at work in relation to the larger site and campus setting. One enters on the oblique, and continually slides in either a counter clock wise or clock wise motion up the building. This was already announced in the 1 April 1960 sketch and the building as movement reinforced as desirable by President Pusey according to Le Corbusier's sketchbook notes of mid June $1960^{13}$. (Fig. 3, 4) The movement continues back down again, sliding always on the edge and compressed by the looming, bulbous volume of either the painting or the sculpture studio to one's side. The building is layered by open Ls (els) cut by the flattened Z-shaped circulation ramp slipping along the edges in a sideling manner. Studio spaces thrust forward in part in a burst of centrifugal energy and there is the implied promise of future vertical extension. With some imagination, the building can be read as folding over itself in an almost boolian movement, as if the ramp were holding down a vertically moving force, the ramp preventing the building from elevating further off the ground.

This can be considered another aspect of Le Corbusier going beyond frontality, and Kenneth Frampton (1930) provides a clue as to what is at stake. To further unpack the formal moves and motivations of this aspect, consider Frampton's description of modern architecturte during these years as trapped by frontality, unable to adopt the "multi-directional spatiality of the De Stijl or Suprematist movements", and "unable to abandon ... [an] emphasis on frontality" . There is evidence of this bias in VAC's reliance on the free plan, column-slab or wall-slab model, horizontally layered within a central regular volume and thus indebted to or relying on a Domino space concept.

\footnotetext{
${ }^{13}$ Le Corbusier Sketchbooks Volume 4, 1957-1964. New York, Cambridge, Mass.: The Architectural History Foundation, The MIT Press in collaboration with the Fondation Le Corbusier, Paris, 1982. Sketchbook P61, figure 566.

${ }^{14}$ Frampton, Kenneth: "John Hejduk and the Cult of Humanism". In A+U (Architecture and Urbanism or Kenchiku to Toshi), N53, May 1975. pp. 141-142. p. 142.
} 


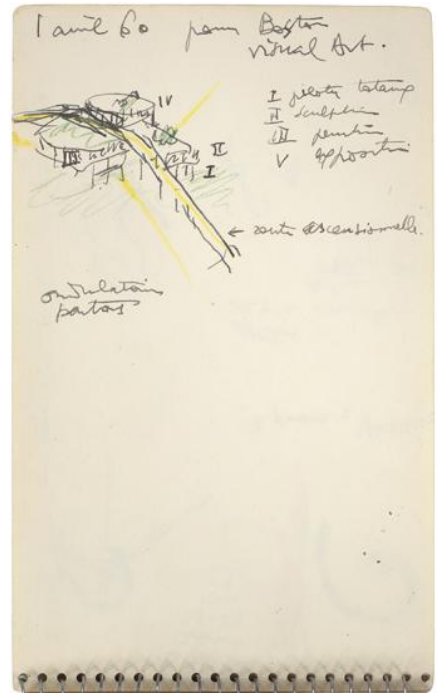

3, Le Corbusier, Sketch of 1 April 1960. (Le Corbusier Sketchbooks Volume 4, 1957-1964. New York, Cambridge, Mass.: The Architectural History Foundation, The MIT Press, 1982. Sketchbook P60, figure 522. (C) Fondation Le CorbusierADAGP, 2015).

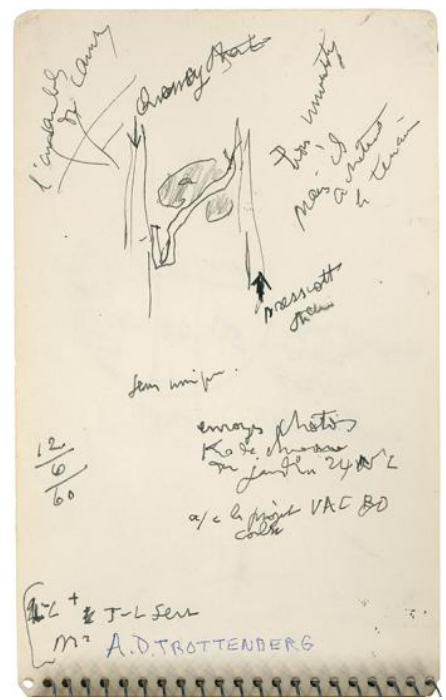

4, Le Corbusier, Sketch dated 12 June 1960 with an emphatic initial forty-five degree rotation and a bias to a larger studio volume on the north. (Le Corbusier Sketchbooks Volume 4, 1957-1964. New York, Cambridge, Mass.: The Architectural History Foundation, The MIT Press, 1982. Sketchbook P61, figure 566. (C) Fondation Le Corbusier-ADAGP, 2015). 


\subsection{Free volumes, or expressive space}

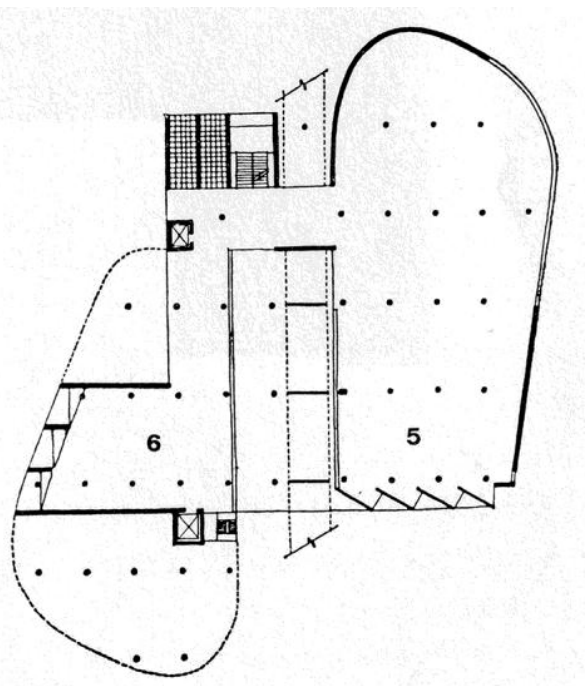

5. Le Corbusier, Visual Arts Center, Level 1 plan. Note the reading of the central square volume has disappeared. (W. E. Boesiger (Ed.), Le Corbusier et son atelier rue de Sèvres 35. Oeuvre complète, volume 7, 1957-1965. Zurich: Les Editions d'Architecture, 1965. p. 54 ( F Fondation Le Corbusier-ADAGP, 2015).

The central rotated square volume of VAC, whose sensation disappears at points, can be claimed to contain two states: horizontal space formed by floor and ceiling planes when extruded (an illustration that is of the Domino diagram) and a line in motion formed by the ramp. (Fig. 5) If one extends the description and abstracts the reading, then one can generalize the differences of these two: planes enclose horizontal space, the line of the ramp elaborates space in it's pull and push and torsion; planes bring into focus providing emphasis, lines dissipate, leading the eye away from a static, single field focus the effect of which is to remove firm boundaries so that a new reality can be created.

We can perhaps say that the building disposes the two studio volumes so as to engender a dynamic space beyond Domino limits to produce what can be characterised as expressive space. This reading is supported by a previously unpublished elevation study of the Prospect Street elevation in a January 1961 development phase, clearly showing the role of the two studio volumes relative to the central one ${ }^{15}$. The demands of expressive space can be considered an evolution of Le Corbusier's free plan into a free section, one animated by organ events and object types, one which might only later be rationalized in terms of site, structure, desired compositional effect or operational need if at all. This sensitivity might extend to a divergence on the one hand toward continuity and on the other toward separation or toward different kinds of continuity where continuity is understood as a unity of space and structure. Separation of supporting point columns and functional partitions: structure does not define space but punctuates it as photographs of the studio spaces in particular demonstrate. Look again at the site planning as providing additional evidence. VAC occupies a relatively flat, urban site and to a certain extent creates its own topography. A consequence of the volume disposition is the use of overlap and strategies of central compression and peripheral dispersion in pursuit of an architectural idea. (Fig. 3, 5, 6, 7)

This line of analysis might suggest that VAC is about movement of volumes and despite appearances is not primarily an illustration of the promenade architecturale. Thus would imply a time concept which differs from

${ }^{15}$ Curtis, 2015, pp. 372-373. 
one aligned with a primarily empirical (chronological) idea of time, one subordinate to movement, a this then that, a past then present, a before and after. In VAC we are never satiated by a space triggered by movement as the ramp's role is constantly denied or deferred: frustrated, it is never allowed to arrive fully; there is no culmination.

We observe then in VAC an intensification of local spatial conditions horizontally and vertically in that junction split between Levels 1 and 2. Those mandolin or lung-shaped organs of the two studios vertically staggered put in motion a spiralling disposition that edges along their Georgian neighbours. Site elements are organised such that a force, or multiple forces, are shaped and temporarily focused only to be quickly dispersed outward so that even in the absence of a peripatetic eye there is still a vibration produced thus recording perhaps a pure time independent of any reliance on motion or movement to bring it forth. If perhaps it is too early to state a preliminary finding, one might thus far be justified in claiming that VAC works equally on concepts of space and on problems of time, though which form of time is unclear at this stage. Another way to characterise this state might be as a mannerist use of shapes and devices that have accompanied Le Corbusier and which differ from other late buildings. At the Millowners' Association Building (Ahmedabad, 1954) ${ }^{16}$, a precedent for VAC on certain elements, the ramp runs straight on, landing frontally at the entry and the lung-like main hall and meeting rooms remain inboard. In the Congress Hall in Strasbourg (unbuilt, 1964) ${ }^{17}$, the organs are also contained whereas at VAC they burst out gripping vice-like the squared volume though not in a centrifugal manner, resulting in ambiguous free organs, perceived as partial figures.

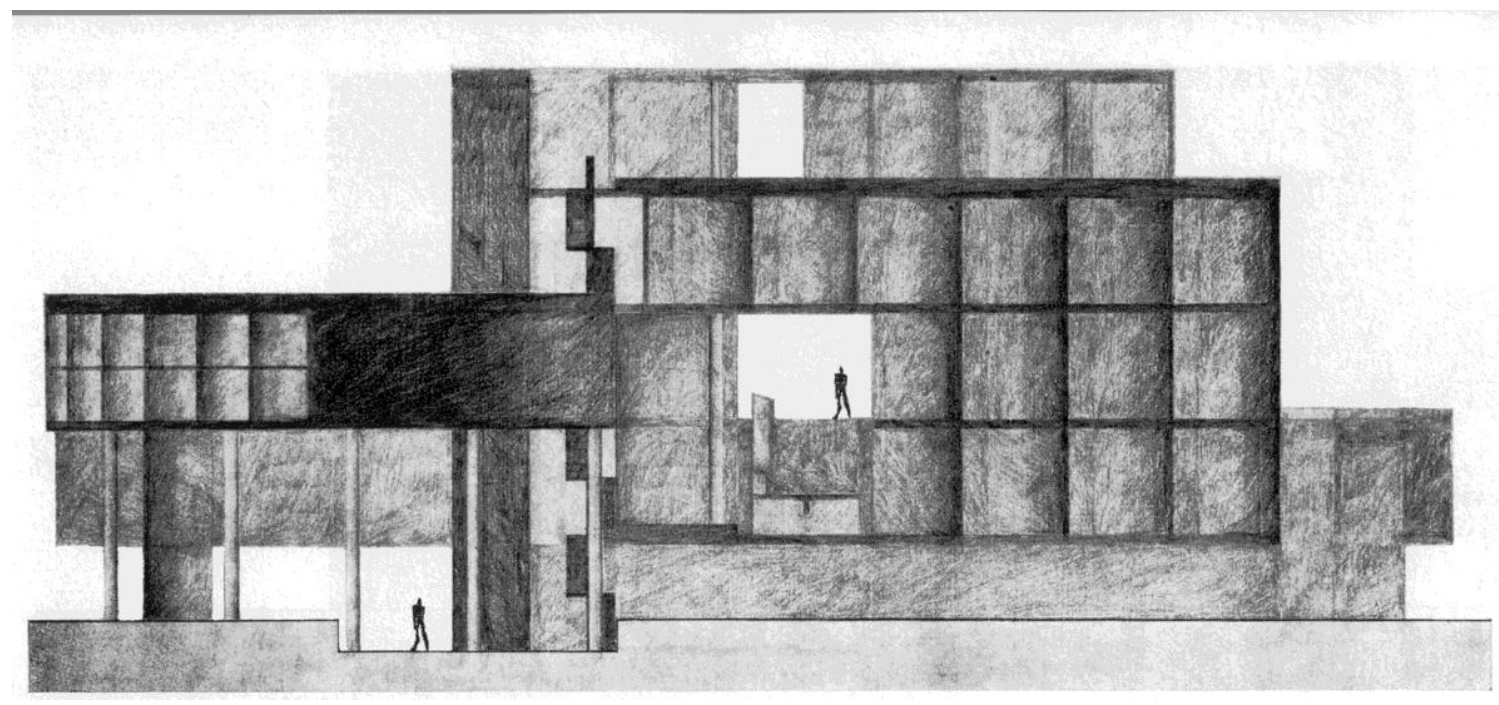

6. Le Corbusier, Visual Arts Center, East façade with ramp. (W. E. Boesiger (Ed.), Le Corbusier et son atelier rue de Sèvres 35. Oeuvre complète, volume 7, 1957-1965. Zurich: Les Editions d'Architecture, 1965. p. 60 () Fondation Le CorbusierADAGP, 2015).

\footnotetext{
${ }^{16}$ W. E. Boesiger (Ed.), Le Corbusier et son atelier 35 rue de Sèvres. Oeuvre complète, volume 6, 1952-1957. Zurich: Les Editions d'Architecture, 1965. pp. 144-157.

${ }^{17}$ Oeuvre complète, volume 7, 1957-1965, pp. 152-163.
} 


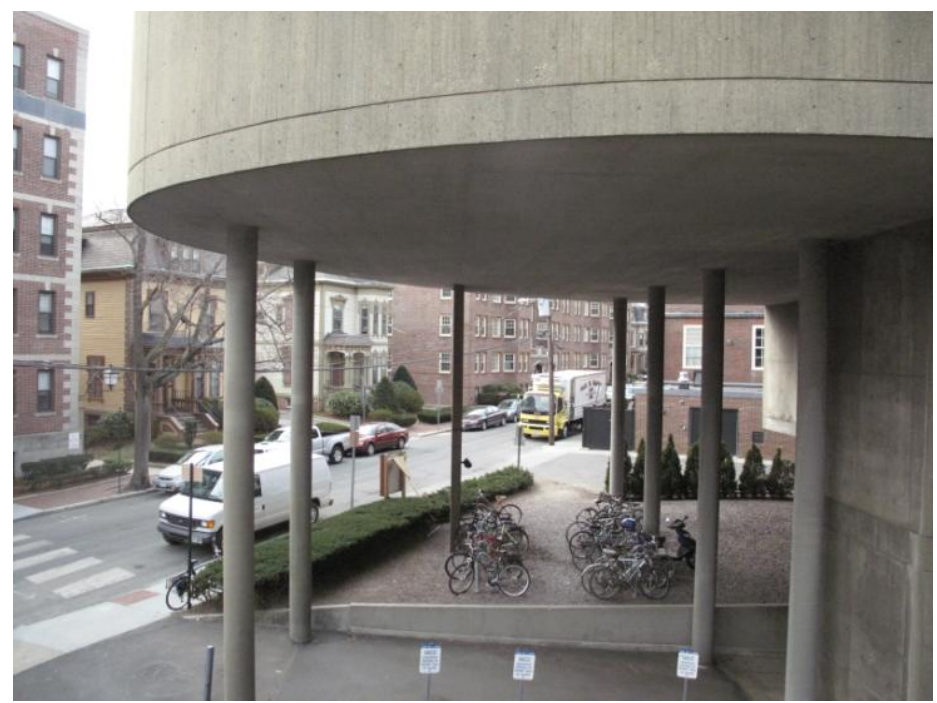

7. Le Corbusier, Visual Arts Center, View under studio space along Prescott Street (@ Fondation Le Corbusier-ADAGP, 2015; Camille Tokerud Photography Inc, 2015).

\subsection{Ambiguities}

“A plan is a section...” John Hejduk ${ }^{18}$

Thus far, a formal analysis of VAC from the point of view of an architectural notion of time has explored two aspects, that of diagonal and transverse relationships engendered by site rotation, and that of external and internal volumes rendered expressive, the consequences in part of free-plan and free-section ideas. In general, as has been suggested, the overall architectural condition is one of complex ambiguities. The building as read is conceived around diagonal movements with functional spaces disposed either as coincident with circulation or as appendages to lines of circulation which bifurcate a volume in rotation creating what might be characterised as a diptych state. This move disrupts or goes beyond an interpretation of frontality.

These traits are neither mutually exclusive nor interdependent but are offered as terms in provisional suspension to allow their reintegration in a future proposition about architectural time.

The third theme to be developed concerns ambiguities in object/field and figure/ground conditions. VAC cannot be fully absorbed from without. Values of wholeness, the ideal of being able to stand at some point and receive a palpable impression of the whole, is specifically not an aim. Even that bird's-eye view sketch from April 1961 only partially outlines some elements but does not yield the complexity of resultant conditions. (Fig. 1, 3, 12) Development of focus is somewhat of an arbitrary and for Le Corbusier intentionally ambiguous proceeding, A potential single, central focus is consistently broken up, concentration in one point is never sought nor gained. Consider the external views which struggle to find a stable viewpoint.

So while this is perhaps too easy a parallel and things are evidently more subtle, can we say that when read at the scale of the site VAC is all figure and no ground and when read internally at the scale of the building all field and no object. In other words, we here confronted with a constant architectural state of middles or of background intensities.

\footnotetext{
${ }^{18}$ Hejduk, 1985, p.73.
} 
This is surely one response, in part, to the fact that in VAC the site and project brief required intensive development as elaborate external deployments were not fully possible within the more or less set and limiting boundaries. Inversion or intensification in the place of extension: more fluid at studio Levels 1 and 2, no less concentrated at the ground and upper floors being bound by those floor and ceiling plates and directed horizontally. Especially if you study the sliding or staggered distribution of main spaces and the dense centre, doubled or echoed by perimeter incidents. Views under and through the studios across the ramp's cut demonstrate this overall field reading. (Figs. 7, 8)

No simple dispersal of focus but more of a constant rebound, waves bounding back to confront initial ripples. In mounting or descending the ramp, the walls of the studios channel the effect. When inside, potential release is denied or multiplied, energy bounced back from or ricocheted off all those perimeter incidents: curving wall, ondulatories, brise-soleils, smooth columns engendering centrifugal forces, aérateurs (vertical narrow pivoting doors with fly screens) channelling space. Peripheral interest in horizontal expansion in the studios; contained concentration of a rather constant nature, sliding and swung along vertically when up and over the ramp.

Look at the plans: the field is a constant condition in the studio spaces ${ }^{19}$. (Fig. 9) A sense of clear volumes is not the main thing: it does not conclude or ever solidify. It is an end but only in a tentative way, an effect of space sliding away along diagonal lines sprung out through brise-soleil, the oblique cut of the end wall in plan and vertical plane. In VAC, the effect of deferred arrival is similar though the means different. Certainly the artist's apartment perched on the final floor might want to satisfy a desire for a conclusion or pyramidal cap. If the internal ramp had been built between the second and third floors, then perhaps in Cambridge the third floor would have gained some hierarchical role but it was not.

If the plan is a section in the work of Le Corbusier as claimed by Hedjuk in his 1965 essay, it is equally valid to claim the section is a plan, one recording ambiguous conditions of overlapping matrices. The square volume is never perceived and is constantly broken up and dissolved. Even in the purest state at Level 3 the stair and lift forever blur the edges from the saw-tooth brise-soleil and create an effect of curious irresolution.

These ambiguities reveal a lingering tendency that might be described as Cubist and Post-Cubist. There is a direction as well as an eccentricity introduced by placement and delineation of walls establishing a dominant direction in organizing spatial flow. These contribute to that constantly shifted centre further, the fourth aspect discussed below. Differing elevation treatments further complicate the readings with brise-soleil, full height fixed glass sheets, and narrow vertical aérateurs providing different kinds of animation.

This could be interpreted as introducing a Cubistic gesture (directional) in a Post-Cubist or Neo-Plasticist (nondirection, square grid) realm. Plan tensions are introduced between a bias to the vertical against uniform extensive or explosive forces, not at the points but out to the edges of the Level 3 diamond plan, precariously balanced on the splitting ramp, all reinforcing the ambiguities and fluctuations in figure and field, matrix and object readings.

\footnotetext{
${ }^{19}$ The as built plans published in Sekler and Curtis, 1978, better demonstrate this condition.
} 


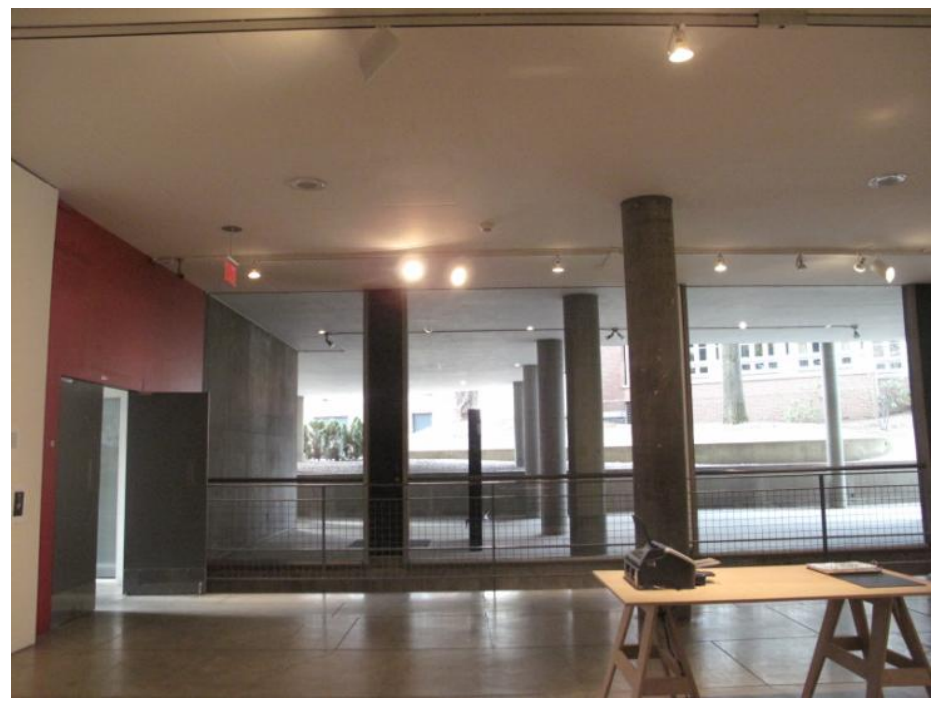

8. Le Corbusier, Visual Arts Center, View through studio space at Ground Floor (@ Fondation Le Corbusier-ADAGP, 2015, Camille Tokerud Photography Inc, 2015).

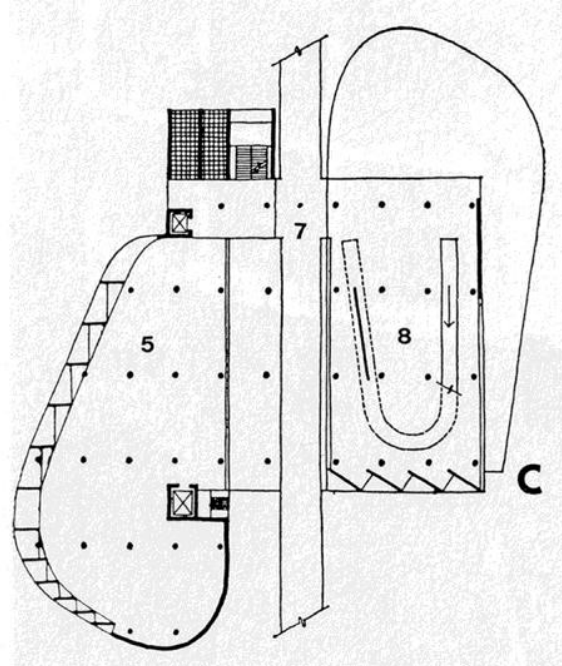

9. Le Corbusier, Visual Arts Center, Level 2 plan, noting the proposed horseshoe ramp linking levels 2 and 3 was not built. (W. E. Boesiger (Ed.), Le Corbusier et son atelier rue de Sèvres 35. Oeuvre complète, volume 7, 1957-1965. Zurich: Les Editions d'Architecture, 1965. p. 55 () Fondation Le Corbusier-ADAGP, 2015).

\subsection{Voided centres}

Form relations, concepts of space, and perhaps as I am proposing notions of time are all being worked on here. At first blush, and as suggested above, two composition devices are constantly explored in VAC. The first, an expansion "or exfoliation toward the periphery and beyond" 20 . A second composition strategy is that of a condensation of space and mass towards an always-voided centre.

This idea of the voided centre confirms a move away from a trabeated logic of post and beam frames, of singular columnar surfaces, and of articulated roofs toward a ground-less architecture of round columns, freestanding partitions, and flat-slab floors and ceilings.

\footnotetext{
${ }^{20}$ The term exfoliation is Kenneth Frampton's, used to characterize tensions in the periphery of Hejduk's contemporary diamond projects and with useful application here. Frampton, 1975, p. 14.
} 
In other words, a critical work on the Domino world of column-slab construction, engaging full on the implications and effects of two kinds of architectural freedoms, those of "liberated space [and] liberated structure" as Hejduk writes in an undated manuscript sheet from the period but which can be approximately dated to 1965-66, thus around the time he was writing his homage for L'Architecture d'aujourd'hui ${ }^{21}$.

To begin, we notice that columns appear to play a fundamental role at VAC. Other conditions on closer inspection, however equally dominate, setting up differences between the (Domino) flat slab and point column, the brise-soleil window walls, and etched floors. A peripheral dispersion of incident in the case of VAC's middle floors and a peripheral, shifting look, an animated vision - largely frontal even if following a switchback or Zshaped pattern - in the case of the central volumes and ramp element. (Fig. 2) In all readings, the geometric centre is a void, a void occupied by a ramp and outdoor slices of space both oblique and diagonal with elevator cores, stairs, slots co-penetrating, attracting attention to the edges. In VAC any assumption of a central focus is relegated to dismembered spaces in a sort of serial installation of interest (organs, events, ribbon-galleries) round the extremities of the plan.

Contradictions and complexity with two different compositional strategies yielding in one regard, however, similar effects. There is no one centre, it being replaced by a kind of indefinite though not neutral space. Never uniform, in fact it is always potentially fully animated such that hierarchy (of figure over ground or object over matrix) is shown specifically not to be the intent as discussed in the previous section. The absence of one dominant centre, produces this other kind of condition, of being always already in an ambiguous kind of middle condition. (Fig. 10, 11, 12)

So while there is perhaps the idea or promise of a denouement, it is endlessly deferred. I believe this is further evidence of a concept of time at work. You never fully arrive, suggesting time itself has always already passed you by, or perhaps the building surpasses time. There is no interior; everything is in a liminal state. This is a shift in emphasis from previous form studies that focus and make manifest a phenomenon of all-over kinetic equilibrium. In the same pendulum arc used to realize the condition for a neutral container, the two together mimic what Hejduk described as a Michelangelo effect, writing: "The effect is like in Michelangelo's architecture. At first there's a sense of a perfectly neutral condition. Then when you begin to penetrate, it becomes kinetic and dynamic ${ }^{, 22}$.

Look again at the structural system as further demonstration of this state. VAC is set out in a rectangular bay grid rotated relative to the bounding streets, generally employing round section columns with local incidents. In terms of consequent volumetrics, there are the narrow horizontal volumes folding back on itself. (Fig 13) VAC is a hybrid of the Domino flat plate point column grid and an assembly of independent organs. A stable interior is of secondary importance with ascendancy given emphasis, especially in the early schemes where certain of the key uses were located at the Level 2 ramp's arrival ${ }^{23}$. As already noted there is a promise of arrival and culmination that is never satisfied.

The voided centre, finally, is revealed in the reading of the horizontal planes of floor and ceiling as dominant in the one reading, the enclosing walls channelling movement and reinforced by a highly articulated and in parts

\footnotetext{
${ }^{21}$ Hejduk, annotations on a sheet of unpublished sketches for Diamond House B, Canadian Center for Architecture, John Hejduk Archive/Fonds 145, Series 2: Professional Work, File 15: Diamond Houses, Sub-file 4: Miscellaneous Diamond House Sketches, drawing DR1998_0063_005.

${ }^{22}$ Hejduk, in interview with Wall, 1985, p.90. On the idea of kinetic equilibrium, see also Hejduk, 1985, p. 52.

${ }^{23}$ As Curtis relates, in the final scheme as built the administration offices were relocated from level two to the ground floor thus removing the programmatic imperative to take the ramp. In Sekler and Curtis, 1978, 139ff.
} 
transparent ceiling and floor in the experience of the ramp in the other. Horizontal extensions are reinforced by the shear, taut, unencumbered ceiling plane matched by a vertical pull of the studio organs, themselves staggered diagonally. In VAC the centre is occupied by a cut, that of the ramp, marking a spring-point of pin-wheeling elements. But contrary to possible assumptions, there is no tension; rather there is a state of ambiguous equilibrium, all the architectural energies moved to the perimeter.

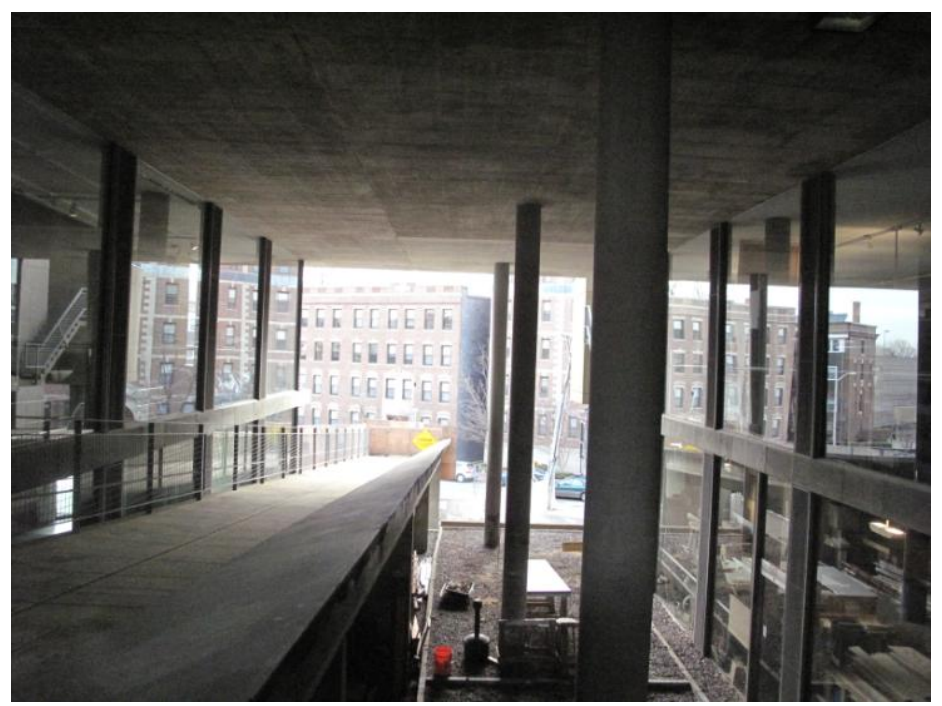

10. Le Corbusier, Visual Arts Center, Ramp between Levels 1 and 2 (@ Fondation Le Corbusier-ADAGP, 2015, Camille Tokerud Photography Inc, 2015).

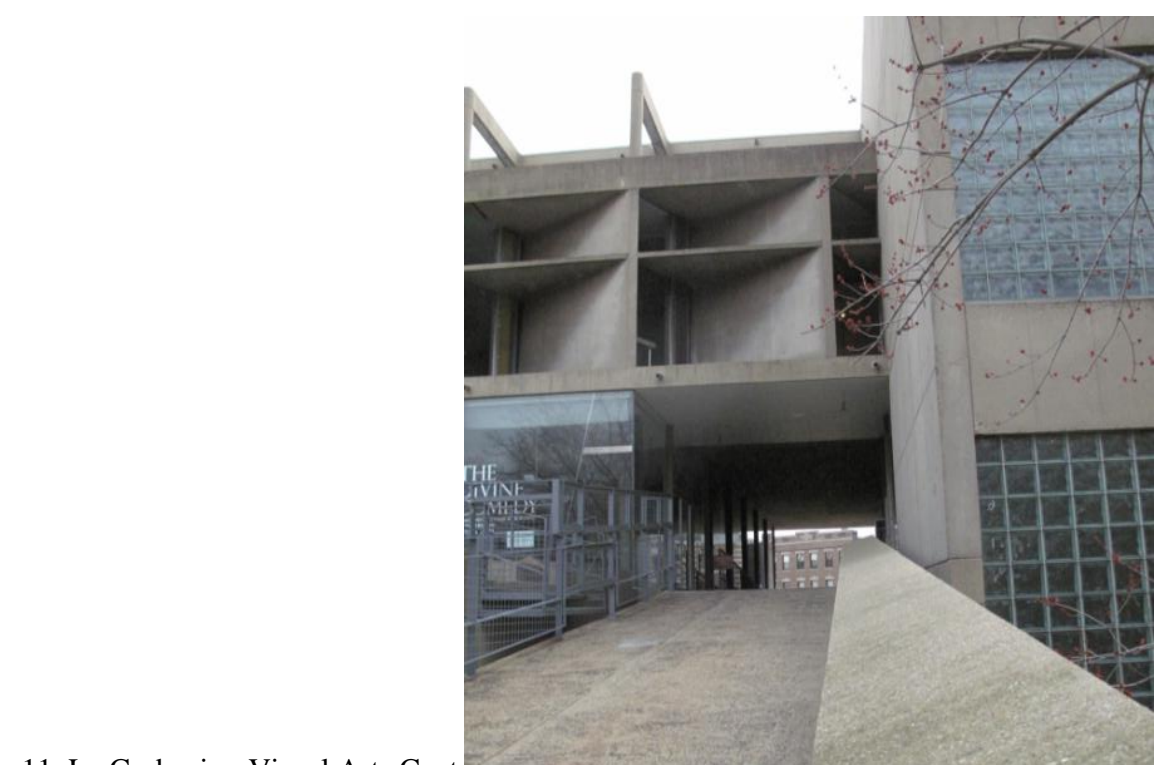

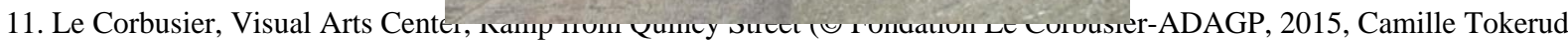
Photography Inc, 2015). 


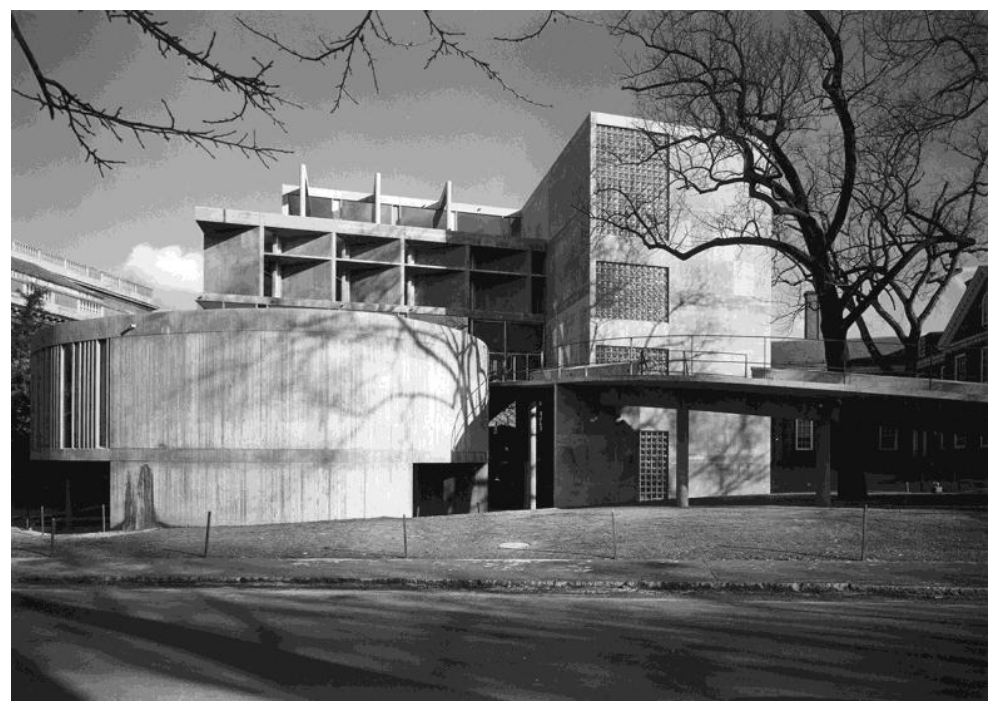

12. Le Corbusier, Visual Arts Center, View from Quincy Street @ Fondation Le Corbusier-ADAGP, 2015).

\section{Conclusion}

“... we are plunged into time, $”$ Gilles Deleuze $e^{24}$

\subsection{Findings}

The four spatial-formal effects now surveyed, we return to the germinal questions and opening propositions around time. Is there a concept of time rendered in VAC, of a time concept specific to a work of architecture? What kind of temporal structures are at work and do they share aspects of being plunged into a direct time? In the too brief proceeding analysis explicit has been the question of a pure time, both as an effect created or made manifest in the building and as an interpretive category. In other words, can we claim some evidence of what I've proposed to call a diagonal time in the Visual Arts Center?

In terms of frontality, which we started with, here is Le Corbusier clearly working to get over or to abandon the limits he sees in a reliance on frontality by at least two moves, that of charging the perimeter and voiding the centre. Linked to all these, and perhaps a first move, there is the rotation of the building relative to to site conditions which allows him to move away from cross axial planning which characterises so much of the layered site planning in his early carer from the Villa at Garches to the League of Nations. For when confronted with the receding or encompassing walls as one approaches up the ramp always on the oblique the observer is always in a transverse state, even without moving. And in the rotation appears a curious, ambiguous notion of time, characterized by Hejduk as a "moment of the present" ${ }^{25}$. It is not just an entry or threshold condition of walls, but the entire project that is working on and intensely occupies the present.

\footnotetext{
${ }^{24}$ Deleuze, 1989, p. xii.

${ }^{25}$ These terms come out during Hejduk interviews in the 1980s: "The place where a perspective or diamond configuration on the horizontal plane flattens out and the focus moves to the lateral peripheral edges... This is the moment of the hypotenuse of the diamond: it is here that you get the extreme condition, what I call the moment of the present. ... It's here that you are confronted with the flattest condition. It's also the quickest condition, the fastest time wise in the sense that it's the most extended, the most heightened; at the same time, it's the most neutral, the most at repose." (Hejduk, 1985, p. 90)
} 
From the above analysis we can perhaps say that VAC renders manifest an idea of time out of joint, one that does not rely on movement to gain presence. Different from Le Corbusier's early period emphasis on an Acropolian sequence, and the motor and visual aspects that implies and the parallax effects so immediate and palpable in that whirl of columns and tilting planes proceeding up and through the building; and despite the combination of oblique movement and peripheral incident dispersed over and across several floors, and the free organs staggered vertically; despite or in addition to all this, time perhaps appears directly.

The four aspects when reviewed together provide a provisional description of its main characteristics: diagonal and transverse relationships, and a voided centre that creates intensity independent of any other animating presence. In addition, there is a specific idea of structure: the flat slab and point structure in VAC overlapping with dense perimeter conditions and the cantilever, lung-like shapes in an open-ended plan. Perhaps supporting or enabling it all, field and ground ambiguities. To varying degrees, and with all the qualifications called for, there is a suggestion of an architectural concept of time. It is one that shares aspects with those post-1945 phenomena described by Deleuze.

Thus we are confronted with forms of simultaneity, with a concept of time as over-lapping durations, the consequence of compressions and release, all working to create folds in, or give thickness to, time. And these seem to be valid and real findings, if only tentative conclusions which nonetheless call for further research with other concrete examples to be sought and terms of reference refined and amended.

Providing a kind of open unity to the form relations and spatial orders at issue - voided centre, peripheral tension, exploded field, volume become plane and thus creating the conditions for flat space to appear - the specific notion of time revealed in VAC is I believe that dimension which ensures a single whole is never completely given. And in this instance, direct or diagonal time would be that function or operation that holds it all together. As suggested in this brief analysis, diagonal time has the strange power to affirm parts that do not make a whole in space, nor form a succession in time. Time is exactly the diagonal of all possible spaces, those made possible as a result of the freedoms Hejduk found in Le Corbusier, that of liberated space and liberated structure. In place of frontality and cross-axial planning, VAC proposes transverse relationships. The ramp's cut displaces a Domino ideal by expressive volumes and partial figures.

The following comparative table lists some characteristics of diagonal time as developed above.

\begin{tabular}{|c|c|}
\hline Linear time & Diagonal time \\
\hline $\begin{array}{ll}\text { - } & \text { Frontality } \\
\text { - } & \text { Cross-axial planning } \\
\text { - } & \text { Domino } \\
\text { - } & \text { Free plan } \\
\text { - } & \text { Contour and simple mass } \\
\text { - } & \text { Hierarchy }\end{array}$ & $\begin{array}{ll}\text { - } & \text { Diagonality } \\
\text { - } & \text { Transverse planning } \\
\text { - } & \text { Expressive volumes } \\
\text { - } & \text { Free section } \\
\text { - } & \text { Ambiguities in figure-ground } \\
& \text { relations } \\
\text { - } & \text { Voided centre }\end{array}$ \\
\hline
\end{tabular}

Table 1. Aspects of diagonal time versus linear time

\subsection{Further lines of research}

A number of lines of further research should be followed, with two already alluded to.

The study of the diagonal in plan and conditions of diagonality as a general condition in mid-twentieth century architecture should be pursued. Efforts might include tracking parallel manifestations of the diagonal in a series 
of architectural projects and a limited number of theoretical-historical texts. On the side of project, the research might start with an interrogation of Hejduk's Diamond Projects series (1962-1967), Eisenman's House projects (1965-1969), and Louis Kahn's (1901-1974) project for the Philadelphia College of Art (1960-1966) each rendering different aspects of the diagonal. In parallel to the formal analyses, the research might examine the diagonal and its various manifestations in period writing and teachings of key architectural historians. Colin Rowe, Vincent Scully (1920) and Rudolph Wittkower (1901-1971) might provide a start. Each theorises to different degrees the modernist project and alludes to the diagonal and related concepts of ambiguity, folding, the oblique, and torqueing.

A second line of expanded research should examine more emphatically whether and by what means Deleuze's notion of direct time provides a way to think about and test different architectural concepts of time, only touched on above. According to Deleuze, a reversal in the relation of movement and time can be discerned in the realms of philosophy and cinema. For philosophy, the reversal has slowly occurred, and only in some thinkers, over hundreds of years whereas in cinema it has occurred since 1945 and thus at a much more accelerated pace with the movement-image of classical cinema being supplanted by a time-image. Deleuze describes certain devices which render time manifest in itself, prior to or proceeding movement and he finds evidence of this condition in certain films of Renoir, Fellini, and Welles among others.

To conclude, and as a final promise to future research, I return to the concept of pure time in Cinema 2. Deleuze succinctly characterises it: there are certain conditions rendered in works of cinema - and by extension I would claim in certain architectural projects - such that one is taken directly into an experience of time irrespective of any reliance on movement. There are certain kinds of aesthetic works so conceived and constructed, he writes, that "... we are plunged into time rather than crossing space",26.

The above is an initial suggestion of the interpretive and creative potential a concept of diagonal time may hold for architecture. An analysis of Le Corbusier's Visual Arts Center has provided an initial case study and further research on other modernist architects would I believe reveal others.

\section{Acknowledgements}

Research on and writing of this paper was in part undertaken while at Columbia University as a Visiting Scholar in 2015 and I'm thankful to Professor Mary McLeod of Columbia's Graduate School of Architecture, Planning and Preservation for her early encouragement. The project benefitted from a period of leave from teaching with the support of Professor Lyndon Anderson, Dean of the Faculty of Arts and Design, University of Canberra, and Professor Dharmendra Sharma, Chair of the Outside Studies Program. Financial support to attend the Le Corbusier 50 years later International Congress was provided by the University of Canberra Faculty of Arts and Design Conference Fund 2015. I thank Dean Anderson, Associate Dean of Research Professor Angelina Russo and Head of Discipline Dr Andrew MacKenzie for their on-going encouragement. Certain themes were explored in a 2014 seminar in advanced architectural analysis and I thank my postgraduate students for their engagement. This paper is dedicated to Camille Tokerud who undertook the photographic analysis. Camille was a true collaborator and the project benefitted from her positive energy and critical eye.

\footnotetext{
${ }^{26}$ Deleuze 1989, p. xii.
} 


\section{Source of images and tables}

Figures 1-6, 9, 12 (C) Fondation Le Corbusier-ADAGP

Figures 7, 8, 10, 11 Camille Tokerud Photography Inc

Table 1 (C) the Author

\section{Bibliography}

Besset, Maurice: Le Corbusier. Translated from the French by Robin Kemball. London: Academy Editions, 1976.

Boesiger, W. E. (Ed.): Le Corbusier et son atelier rue de Sèvres 35. Oeuvre complète, volume 6, 1952-1957. Zurich: Les Editions d'Architecture, 1965.

Boesiger, W. E. (Ed.): Le Corbusier et son atelier rue de Sèvres 35. Oeuvre complète, Volume 7, 1957-1965. Zurich: Les Editions d'Architecture, 1965.

Colquhoun, Alan: "Formal and Functional Interactions: A Study of Two Late Buildings by Le Corbusier". In Essays in Architectural Criticism: Modern Architecture and Historical Change. Cambridge, Mass.: The MIT Press, 1981. pp. 31-41.

Colquhoun, Alan: "Die Fassade in ihren modernen Varianten". In Werk, Bauen + Wohnen, $\mathrm{N}^{\mathrm{o}} 12$, December 2005. pp. 12-19.

Curtis, William J. R.: Le Corbusier. Ideas and Forms, 2nd ed. London: Phaidon Publishing, Inc., 2015.

Deleuze, Gilles: Cinema 2 The Time-Image. Translated from the French by Hugh Tomlinson and Robert Galeta. Minneapolis: University of Minnesota Press, 1989.

Eisenman, Peter: Inside Out Selected Writings 1963-1988. New Haven: Yale University Press, 2004.

Eisenman, Peter: Ten Canonical Buildings 1950-2000. New York: Rizzoli, 2008.

Frampton, Kenneth: "John Hejduk and the Cult of Humanism". In $A+U$ (Architecture and Urbanism or Kenchiku to Toshi), N53, May 1975. pp. 141-142.

Hejduk, John: "Hors du temps dans l'espace". In L'Architecture d'aujourd'hui. $\mathrm{N}^{\mathrm{o}} 122$, September-November 1965. pp. xxi, xxiii.

Hejduk, John: "Out of Time and Into Space”. In John Hejduk. Mask of Medusa: Works 1947-1983. Edited by K. Shkapich. New York: Rizzoli International, 1985. pp. 71-75.

Le Corbusier: New World of Space. New York and Boston: Reynal \& Hitchcock and The Institute of Contemporary Art, 1948.

Le Corbusier Sketchbooks Volume 4 1957-1964. New York, Cambridge, Mass.: The Architectural History Foundation, The MIT Press, 1982.

Rowe, Colin: The Mathematics of the Ideal Villa and Other Essays, Cambridge, The MIT Press, 1976.

Rowe, Colin and Slutzky, Robert: “Transparency: Literal and Phenomenal”. In Perspecta, No.8, 1963. pp. 4554.

Sekler, Eduard F. and Curtis, William: Le Corbusier at Work. The Genesis of the Carpenter Centre for the Visual Arts. Cambridge, Mass.: Harvard University Press, 1978.

Serenyi, Peter (Ed.): Le Corbusier in Perspective. Englewood Cliffs, New Jersey: Prentice-Hall, Inc., 1975.

von Moos, Stanislaus: Le Corbusier. Elements of a Synthesis. Cambridge, Mass.: The MIT Press, 1979. 